\title{
Groundwater contamination and its effect on health in Turkey
}

\author{
Alper Baba • Gokmen Tayfur
}

Received: 24 May 2010 / Accepted: 27 January 2011 / Published online: 19 February 2011

(C) Springer Science+Business Media B.V. 2011

\begin{abstract}
The sources of groundwater pollution in Turkey are identified, and pathways of contaminants to groundwater are first described. Then, the effects of groundwater quality on health in Turkey are evaluated. In general, sources of groundwater contamination fall into two main categories: natural and anthropogenic sources. Important sources of natural groundwater pollution in Turkey include geological formations, seawater intrusion, and geothermal fluid(s). The major sources of anthropogenic groundwater contamination are agricultural activities, mining waste, industrial waste, on-site septic tank systems, and pollution from imperfect well constructions. The analysis results revealed that natural contamination due to salt and gypsum are mostly found in Central and Mediterranean regions and arsenic in Aegean region. Geothermal fluids which contain fluoride poses a danger for skeleton, dental, and bone problems, especially in the areas of Denizli, Isparta, and Aydin. Discharges from surface water bodies contaminate groundwater by infiltration. Evidence of such contamination is found in Upper Kizılırmak basin, Gediz basin, and Büyük Melen river basin and some drinking
\end{abstract}

\footnotetext{
A. Baba $(\bowtie) \cdot$ G. Tayfur

Department of Civil Engineering,

İzmir Institute of Technology,

Urla, İzmir, Turkey

e-mail: alperbaba@iyte.edu.tr
}

water reservoirs in İstanbul. Additionally, seawater intrusion causes groundwater quality problems in coastal regions, especially in the Aegean coast. Industrial wastes are also polluting surface and groundwater in industrialized regions of Turkey. Deterioration of water quality as a result of fertilizers and pesticides is another major problem especially in the regions of Mediterranean, Aegean, Central Anatolia, and Marmara. Abandoned mercury mines in the western regions of Turkey, especially in Çanakkale, İzmir, Muğla, Kütahya, and Balıkesir, cause serious groundwater quality problems.

Keywords Groundwater • Pollution • Waste • Health • Turkey

\section{Introduction}

Water is the basis of life on this planet and the foundation of civilization. Human beings obtain their water supplies from streams, lakes, surface water, and groundwater. Throughout history, the development and management of water resources, together with policies regarding their use, have evolved in a variety of ways. In Turkey, for example, irrigation projects were constructed thousands of years ago to grow food and fiber. The region between the Tigris and Euphrates rivers was known as the Fertile Crescent in large part 
because of the abundance provided by ancient irrigation projects (Cech 2003).

Even though being essential for life, water also remains the most important factor of illness and infant mortality in many developing countries and even in industrialized countries, where the number of cases of infectious intestinal diseases continues to increase (Jones and Watkins 1985). Due to recent rapid technological developments and population increase, water resources such as groundwater are in danger of severe pollution in the world, including Turkey.

Groundwater contamination can be classified as having either natural or anthropogenic sources. Natural groundwater contamination is mainly due to geological formation with shallow groundwater mass (water-rock interaction in cold waters), infiltration from low-quality surface water bodies (streams, rivers, lakes), seawater intrusion, or due to the effect of geothermal fluids (waterrock interaction in hot waters). Anthropogenic groundwater contamination is generally ascribed to extreme use of agricultural pesticides and fertilizers, mining wastes, disposal of industrial wastes, waste disposal sites, and imperfect well construction.
Turkey which is located at the crossroads of Europe and Asia and extends over the Dardanelles and Bosphorus straits allowing a natural connection between the Mediterranean and the Black Sea covers a total area of $779,452 \mathrm{~km}^{2}$, of which $14,300 \mathrm{~km}^{2}$ is occupied by water (Fig. 1). According to the Turkish General Directorate of State Hydraulic Works (DSI), the total water potential of Turkey totals 234 billion $\mathrm{m}^{3}$, and its gross potential of water available per capita per year, as of 2010 , is about $1,600 \mathrm{~m}^{3}$. The annual surface water potential is about 193 billion $\mathrm{m}^{3}$. In addition to its surface water resources, the groundwater potential of Turkey has been a focus of numerous studies since 1956. It is estimated that Turkey's total annual groundwater resource is approximately 14 billion $\mathrm{m}^{3}$. The total usable annual surface and groundwater potential of Turkey is 112 billion $\mathrm{m}^{3}$ (DSI 2010). Due to its rapid industrialization and urbanization, it is recorded that domestic, hospital, and industrial wastes have become a threat to groundwater in most parts of Turkey (Aslan and Akkaya 2001; Afşin 1997; Baba and Ayyıldız 2006; Baba and Ármannsson 2006; Ekmekçi 2005; Ekmekçi and Günay 1997; Elhatip 1997; Gemici 2008; Karagüzel et al. 1999;

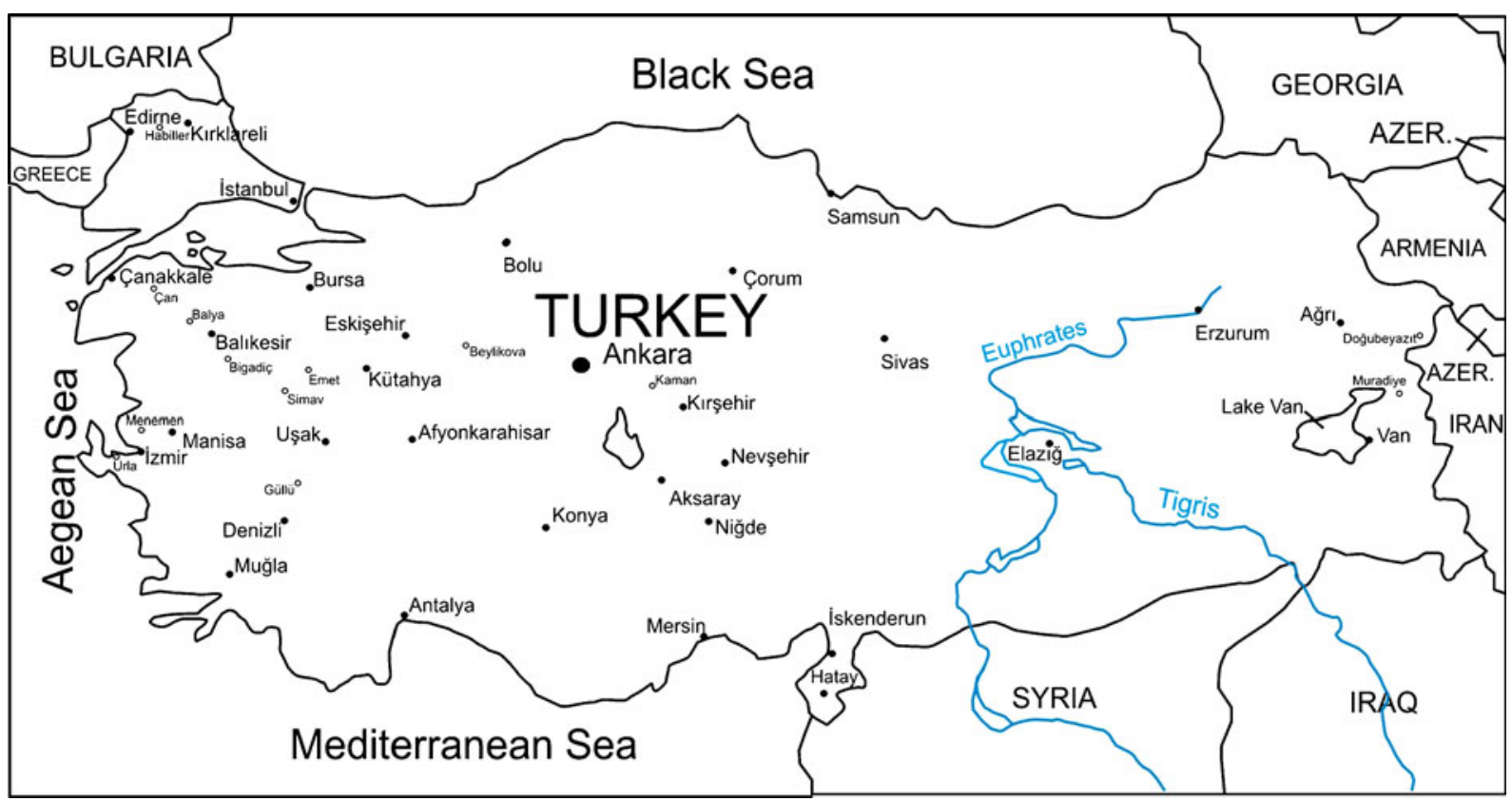

Fig. 1 The map of Turkey 
Kaçaroğlu 1999; Kalavrouziotis and Alaton 2008; Tayfur et al. 2008; Yazıcigil et al. 2009).

Important sources of natural groundwater pollution in Turkey include geogenic factors, seawater intrusion, and geothermal fluids. The major sources of anthropogenic groundwater contamination in Turkey are agricultural activities, mining activity, industrial waste, and on-site septic tank systems. This study examines all the possible pollution sources of groundwater and its adverse health effects in Turkey.

\section{Natural groundwater contamination}

\section{Geogenic factors}

Groundwater quality can be altered by geological formations. This type of quality change is known as water-rock interaction (Hem 1985). Waterrock interactions in cold waters exist in shallow depths of groundwater and geological formations. For instance, leaching heavy metals from ore deposits, hardness from carbonate rocks such as dolomite and limestone, and heavy metal inputs such as boron, fluorine, and arsenic via rising geothermal fluids are some examples of natural groundwater contamination in Turkey owing to its complex geology and being one of the most active regions in the world.

The repeated opening and closing of the Paleozoic and Mesozoic oceans have dominated the geological and tectonic evolution of Turkey (Dewey and Şengör 1979; Jackson and Mc Kenzie 1984). The continental collision between the African and Eurasian plates results in complex deformation of the Mediterranean Earthquake Belt in which Turkey is located (Bozkurt 2001). The border of these major plates constitutes seismic belts which are marked by young active faults and volcanism (Fig. 2). Because of the neotectonic structure and volcanism(s), various altered rock types affect the water source quality. Based on the tectonic characteristics and the geological structure, many parts of Turkey are likely to have arsenic containing geological formations within which groundwater is also likely to contain high arsenic levels. As a result of that, deterioration of groundwater quality has been a popular issue in public milieu. Recently, arsenic pollution has become an important topic in the agenda of Turkey. Particularly,

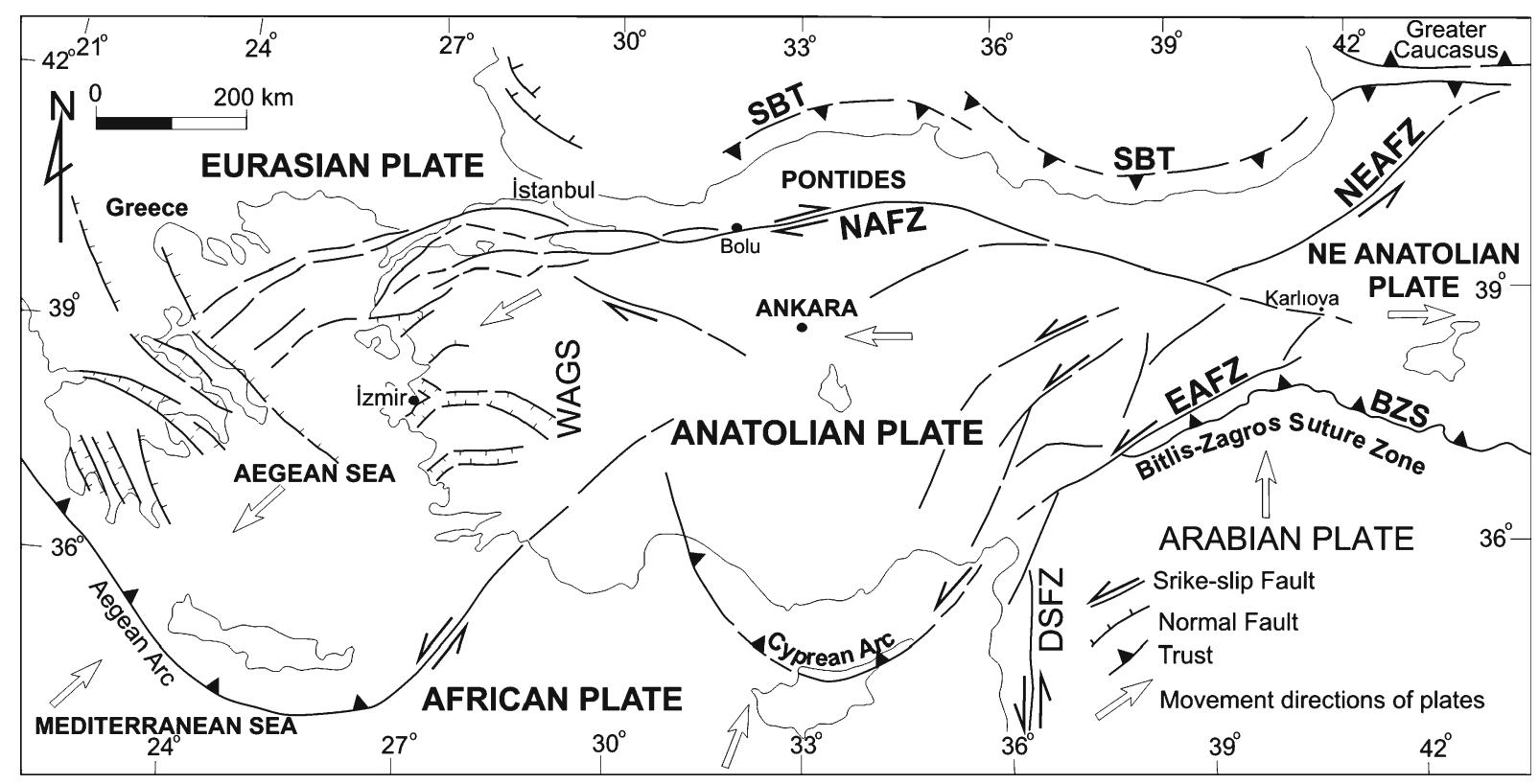

Fig. 2 Simplified tectonic map of Turkey with major neotectonic structures and provinces (modified from Yiğitbas et al. 2004) 
high arsenic levels have been detected in the drinking water supply systems of large metropolitan areas. Groundwater sources in the provinces of Aksaray, Afyon, İzmir, Manisa, Nevşehir, Kırklareli, Kütahya, Balıkesir, and Van (Fig. 1) have a high concentration of arsenic whose enrichment in groundwater is of global concern. High As concentrations are found in groundwater for various reasons: discharge of thermal water, leaching of As from tertiary volcano-clastic sediments, and release of sorbed As where redox conditions in groundwater are reduced (Gemici 2004; Gemici and Tarcan 2007; Yilmaz et al. 2009). Many kinds of alteration exist in western part of Turkey where intense zones of silicified, propylitic, and argillic alteration can be observed (Baba and Gündüz 2009; Gündüz et al. 2010; Baba 2010). Weathering and dissolution of arsenic minerals, waterrock interactions, and geothermal processes cause groundwaters to be enriched in arsenic.

The concentration of arsenic in groundwater in İzmir, Afyon, and Van has increased from 32 to 59 and from 41 to 44 and 38 to $40 \mathrm{ppb}$, respectively (Radikal newspaper, 2008). For example, $40 \%$ of the city of İzmir's water comes from the Göksu and Sarıkız (Manisa) drill holes. The concentration of arsenic in these drill holes exceeds the drinking water limits (10 ppb) and signs carcinogenic risks (Kavcar et al. 2009). All this contamination is related to geological formation. Also, arsenic is one of the major pollutants in Bigadiç (Fig. 1) and showed high spatial variation ranging from 33 to $911 \mu \mathrm{g} / \mathrm{L}$ in groundwater samples. Arsenic values increased close to the Simav and Günevi mines (located near Bigadiç), reaching $305 \mu \mathrm{g} / \mathrm{L}$, and decreased to the south of Bigadiç area (Gemici et al. 2008) and also in the Simav plain, reaching 561 g/L (Gündüz 2009; Gündüz et al. 2009).

The higher elevation grounds of İzmir (Bornova, Yamanlar, and Çiğli regions located in the northern part of the city) are formed by volcanic rocks. Yamanlar and Çiğli volcanic rocks contain mineralized zones. Due to precipitation, especially during the spring and autumn, heavy metals are released into groundwater (Baba et al. 2001; Baba and Ayyıldız 2006).

Fluoride is another important issue on groundwater quality in Turkey. This is because there are widespread fluoride deposits in Turkey, high solubility of the element (water-rock interaction), and medical concern on the basis of excess fluoride intake. Analyses of 13 surface and groundwater samples from Güllü Village in the province of Uşak showed fluoride concentrations between 0.7 and 2 ppm (average 1.35, median 1.60; Oruc and Vicil 2001). Examining of drinking water sources around the villages of Beylikova-Kızılcaören (Eskişehir), Uslu (1982) and Fidanci et al. (1994) found fluoride concentrations around 3.9-4.8 and 2.0-9.2 ppm, respectively. Beylikova-Kızılcaören is well-known in Turkey for fluoride production. Kaman-Bayındır (Kırşehir) is another famous region for fluoride formation, and groundwater in the region contains approximately $2.6 \mathrm{ppm}$ of fluoride (Fidanci 1997). Fluoride contamination in groundwater has also been observed in the Doğubeyazıt (Ağrı), Muradiye (Van), and Habiller (Edirne) regions (Sendil and Baysu 1973; Oruc 1977; Uslu 1982; Baba and Ayyıldız 2006).

Formations which contain salt, gypsum, and anhydrite result in salt and sulfate pollution exceeding irrigation and drinking water limits in Turkey. Some parts of the İskenderun (Uluçınar and Arsuz plains, the central part of the Asi Basin) and areas around Sivas and Çorum are at risk (Fig. 1). The solubility of gypsum is very high when compared to many other minerals (Tayfur et al. 1995). Surface water and groundwater contacting gypsum formations can easily attain significant total dissolved solids (TDS), calcium, and sulfate contaminations. This will prevent their usage for drinking, domestic, industrial, and irrigation purposes. Gypsum formations containing halite interlayer crop out in a large area of the Upper Kızılırmak Basin, Sivas. Kaçaroğlu et al. (2001) studied the effects of the lithological composition of the catchments area on the water chemistry and quality in the Upper Kizllırmak Basin. Surface waters draining gypsiferous areas and the springs of Goydun and Seyfe create high TDS concentrations in the River Kizllırmak $\left(\mathrm{EC}=1,100-5,200 \mu \mathrm{S} \mathrm{cm} \mathrm{cm}^{-1}\right)$. The Goydun and Seyfe springs, which originates from gypsum rich deposits, have very high TDS values $(\mathrm{EC}=$ $\left.12,825-13,900 \mu \mathrm{S} \mathrm{cm}^{-1}\right)$. Surface and groundwater resources in non-gypsiferous parts of the Upper Kizılırmak Basin, specifically in the River Yıldı, 
and the Kaynarca and Gaziköy springs in the Tavra Valley have lower TDS. The EC of these waters ranges between 495 and 630, 795 and 995, 530 and $575 \mu \mathrm{S} \mathrm{cm}^{-1}$, respectively. The water of the Goydun and Seyfe springs and the Kizilırmak River alluvium are not suitable for drinking, irrigation, or industrial purposes. The TDS, hardness, sulfate, and chloride concentrations of these waters exceed maximum permissible Turkish Drinking Water Standards. Their very high salinity and sodium hazard also prevents their use for irrigation (Kaçaroğlu et al. 2001; Baba and Ayyıldız 2006). Another example is given by Çelik and Yıldırım (2006) who investigated groundwater pollution from the Çavuşçayı basin, SungurluÇorum. Çelik and Yıldırım (2006) reported that groundwater is mostly affected by salty $\left(\mathrm{Na}^{+} \mathrm{Cl}^{-}\right)$ waters of the Incik Formation which is used for salt production and brackish $\left(\mathrm{Ca}^{2+}, \mathrm{Mg}^{2+} \mathrm{SO}_{4}^{2-}\right)$ waters of the Bayındır Formation.

\section{Quality of surface water}

Due to wells drilled in the Lakes Region in Turkey, salty and acidic lake waters have penetrated into the local aquifers (Burak et al. 1997). Studies carried out between 1997 and 1998 showed that the groundwater of the Eskişehir plain, especially around the city center, does not meet drinking water quality standards. In this region, reasons for the groundwater contamination vary, but the most important one is the mixing of the Porsuk Stream and irrigation channel waters with the groundwater (Özçelik and Sarız 2001). Another example is given by Karamenderesi and Helvaci (2001) who investigated groundwater pollution from the Büyük Menderes River. Karamenderesi and Helvaci (2001) reported that uncontrolled excessive abstraction of groundwater caused polluted surface water from the Büyük Menderes to infiltrate into the aquifer around the river. They also indicated that water contamination in the Büyük Menderes River affected the ecology of the local geothermal systems (Baba and Ayyıldız 2006).

The River Büyükmelen exceeds the limit values permitted by the World Health Organization and Turkish standards. Since water from the River Büyükmelen is considered to be used as drinking water, it will have an adverse effect on drinking water quality and consequently on health, if not treated in advance. The existence of $\mathrm{Mn}$ and $\mathrm{Zn}$ in the Elmalı drinking water reservoir of İstanbul and $\mathrm{Fe}$ in the River Büyükmelen water indicates natural inorganic contamination. Mn, $\mathrm{Zn}$, and Fe contents in the water are of geological origin (Pehlivan and Yilmaz 2005). The average surface water quality around Istanbul is classified as slightly polluted in Darlık, Terkos, Büyükçekmece, and Alibeyköy and highly polluted in Elmalı reservoir. Poor water quality in the reservoirs is attributed to urban settlement, industry, and farms in the catchment areas (Selçuk et al. 2004).

\section{Saltwater intrusion}

The two major types of groundwater reservoirs in Turkey are alluvial plain aquifers and highly karstified carbonate rocks aquifers. The alluvial aquifers that exit along the coastal area are usually of low yield and threatened by saline water intrusion (Yazıcigil and Ekmekci 2003). Groundwater can be polluted by seawater intrusion due to excessive abstraction of groundwater from coastal wells. In coastal plains such as Çeşme (İzmir), Bodrum (Muğla), Gökçeada (Çanakkale), Marmaris (Muğla), Çanakkale, Erzin (Hatay), Kazanlı (Mersin), and Turgutreis (Muğla), groundwater has been either completely or partially affected by seawater (Baba and Deniz 2004; Baba and Yiğitbas 2007; Burak et al. 1997; Gemici and Filiz 2001; Gürçay 2004; Demirel 2004; Emekli et al. 1996). Around the Çeşme peninsula (İzmir) and Bodrum peninsula (Muğla), during summer when groundwater abstraction is high, water levels decrease below sea level. As a result, seawater easily penetrates into the landwards.

Karstification is one of the most important factors affecting seawater penetration into aquifers (Fig. 3). In the central parts of the Bodrum region, $\mathrm{Mg}, \mathrm{Ca}$, and $\mathrm{HCO}_{3}$ are the dominant ions, while in regions close to shorelines $\mathrm{Na}$ and $\mathrm{Cl}$ are dominant. In general, the $\mathrm{Cl}$ concentration in groundwater varies from 100 to $200 \mathrm{mg} / \mathrm{L}$, but it can be as high as $4,000 \mathrm{mg} / \mathrm{L}(18 \%$ seawater) when seawater intrusion is occurring (Gemici and Filiz 2001). Therefore, groundwater obtained 


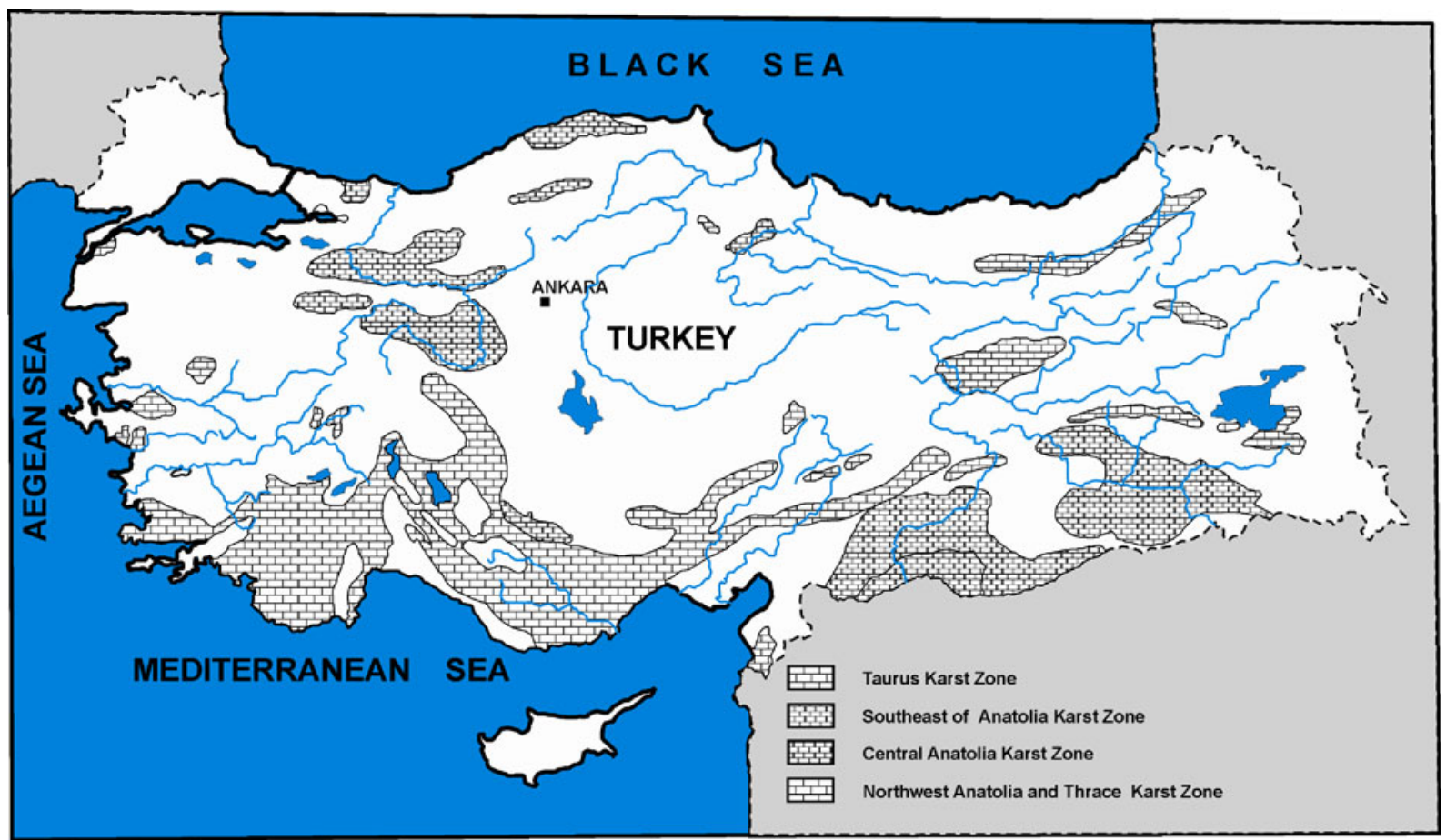

Fig. 3 Karstic map of Turkey (simplified from Eroskay and Günay 1979)

from coastal karstic aquifers is usually salty and hard. In addition, they are not suitable for drinking water. In Bodrum, due to seawater intrusion, saltiness was observed in groundwater (Filiz et al. 1998). Bodrum is a coastal region and karstic formations are commonly present, excessive pumping of groundwater results easily in contamination by seawater intrusion. Therefore, in some parts of the region, the proportion of seawater in pumped groundwater can be as high as $28 \%$ (Filiz et al. 1998). Also, a study carried out in Erdemli (Mersin) between 1999 and 2000 showed that seawater intrusion is also present in this region (Değirmenci and Altın 2001).

In a different study, Özler (2003) studied salinization of groundwater due to salt intrusion from Lake Van (Fig. 1). Van coastal aquifer is one of the main sources of potable, industrial, and irrigation water because surface water is limited due to the semi-arid climate. Groundwater abstraction has been in excess of replenishment owing to increased agricultural and industrial activity and a growing population during the last 20 years. Özler (2003) concluded that the main processes influencing groundwater chemistry are salt-water intrusion, silicate mineral dissolution, cation exchange, and anthropogenic pollution (Baba and Ayyıldız 2006).

\section{Geothermal fluids}

Geothermal waters occur in deep portions of aquifer systems in Turkey. As thermal waters flow through rocks, they dissolve and transport many chemical elements. As a result of the dissolution, groundwater quality decreases (Nicholson 1993). Geothermal waters contain a high concentration of boron, and they may also contain heavy metals such as arsenic, mercury, cadmium, lead, or chromium. At high concentrations, these elements may be fatal for human health (Baba 2004).

Several geothermal water systems are present in Turkey (Fig. 4), and they have been used for numerous industrial and recreational activities. Many groundwater quality studies have been carried out around the Gediz and Aşağı Menderes Plains' geothermal fields. In the geothermal fields of the Afyon-Akarçay Basin, including the 


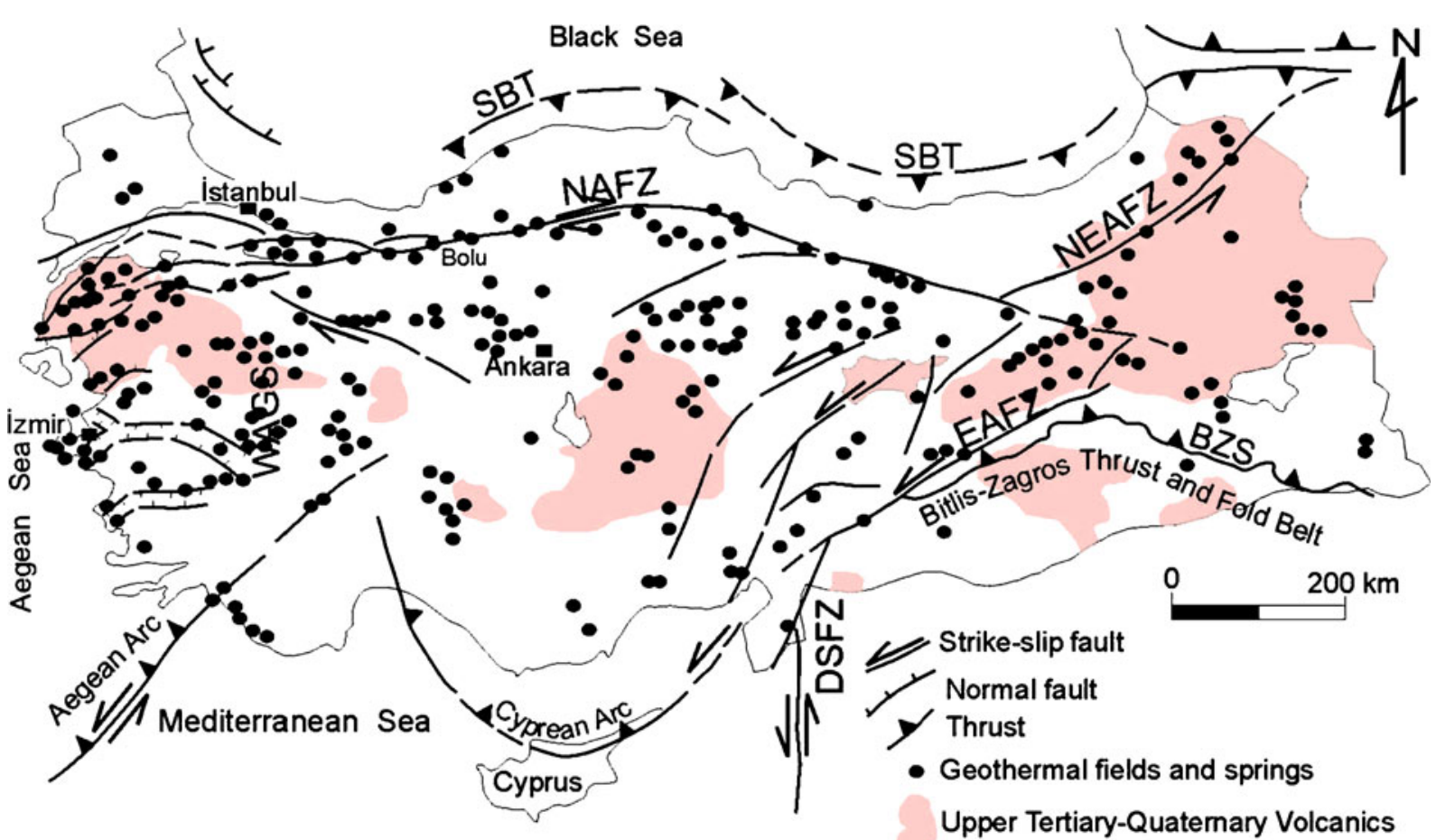

Fig. 4 Simplified main neotectonic lines and hot spring distribution of Turkey (simplified from Şimsek 1997 and Yiğitbas et al. 2004)

Ömer-Gecek, the Gazlıgöl, and the Heybeli fields, geothermal pollution of cold groundwater has been examined. Hydrochemical analyses indicate that the thermal waters are of $\mathrm{Na}-\mathrm{Cl}$ type, whereas the cold groundwaters are of $\mathrm{Ca}-\mathrm{HCO}_{3}$ type. Using $\mathrm{Na}, \mathrm{K}, \mathrm{Cl}, \mathrm{Li}, \mathrm{B}$, temperature, and conductivity as indicators of thermal water mixing indicated that cold groundwater pollution is occurring around geothermal fields in the AfyonAkarçay region (Doğdu and Bayarı 2002; Baba and Ayyıldız 2006).

Boron and selenium transport processes in saturated and unsaturated zones involve many dynamics, and their high levels can cause serious environmental problems (Tayfur et al. 2010a, b). Generally, B concentrations are high in thermal water in Turkey. This is related to volcanic and sedimentary rocks (Fig. 4). The geothermal fields of western Turkey provide a unique setting of high temperature combined with a large variation in chemical composition. For example, effluents from the power plant in DenizliKizıldere where B concentrations are greater than
$20 \mathrm{mg} / \mathrm{L}$ are released into adjacent creeks so endanger natural biota that are sensitive to $\mathrm{B}$ (Gemici and Tarcan 2002). The thermal wastewater of the Kizildere geothermal area contaminates the Büyük Menderes River too. B contamination in this river is an example of surface water contamination by geothermal fluids. The Büyük Menderes Basin is one of the most important basins in Turkey, and its river water is extensively used for irrigation. The main sources of geothermal contaminants are fluids from the geothermal power generation plant at Kizıldere.

Similar problems are known in other parts of Turkey, e.g., the B concentrations in KurşunluÇavundur (Çankırı; $63.8 \mathrm{mg} / \mathrm{L}$ ), Düzce-Derdin (Sakarya; $50.6 \mathrm{mg} / \mathrm{L}$ ), Germencik (Aydın; $69 \mathrm{mg} / \mathrm{L}$ ), and Kurşunlu-Salihli (Manisa; $65 \mathrm{mg} / \mathrm{L}$ ) thermal fluids are extremely high (Baba and Ármannsson 2006). Monitoring of surface water and shallow aquifers inside and outside of the Tuzla (Çanakkale) geothermal field during the period August 2003 to May 2004 led to the detection of the evidence of surface water and shallow 
aquifer contamination due to geothermal fluid (Baba et al. 2005). Tayfur et al. (2010a) modeled boron transport in saturated and saturated zones.

\section{Anthropogenic groundwater contamination}

\section{Agricultural activities}

Fertilizers and pesticides are commonly used in modern agriculture. This increases the risk of groundwater contamination, especially when the agricultural fields are exposed to hazardous chemicals for lengthy periods. Human activity and agriculture have had direct and indirect effects on the groundwater contamination in the area of the İncesu-Dokuzpınar springs (Kayseri). Direct effects are the dissolution and transport of the excessive quantities of fertilizers and hydrological modifications related to irrigation and drainage. Indirect effects may be the changes in waterrock reactions in soils and aquifers which are caused by increased concentrations of dissolved oxidants, protons, and major ions. Agricultural activities have directly or indirectly affected the concentrations of a large number of inorganic chemicals in groundwater in the region, including $\mathrm{NO}_{3}, \mathrm{~N}_{2}, \mathrm{Cl}, \mathrm{SO}_{4}, \mathrm{H}, \mathrm{K}, \mathrm{Mg}, \mathrm{Ca}, \mathrm{Fe}, \mathrm{Cu}, \mathrm{B}, \mathrm{Pb}$, and $\mathrm{Zn}$, as well as a wide variety of pesticides and other organic compounds. The high concentrations of $\mathrm{NO}_{3}$ and $\mathrm{NaCl}$ show that the area around the springs has been continuously contaminated by the untreated sewage and agricultural wastes (Elhatip et al. 2003; Baba and Ayyıldız 2006).

In Aegean region around Urla and Menemen (provinces of İzmir; Fig. 1), groundwater contamination has been detected, resulting from fertilizers and pesticides used in agricultural activities. Aslan et al. (2001) collected water samples from 14 wells from the region and tested for nitrate. Nitrate pollution was observed in two wells In Menemen $(146,53 \mathrm{mg} / \mathrm{L})$. Nitrate pollution was observed in six wells in Urla region $(126,127,98,81,69$, and 69 mg/L; Aslan et al. 2001; Baba and Ayyıldız 2006). In Nilüfer and Ayvalı basins (Bursa), Şen (1996) measured nitrate concentrations in 35 well and spring locations and indicated that the concentrations in these regions were above World Health Organization Standard levels (Şen 1996).
Eryurt and Sekin (2001) drilled five wells in Manisa region to determine the nitrate $\left(\mathrm{NO}_{3}\right)$, nitrite $\left(\mathrm{NO}_{2}\right)$, and ammonium $\left(\mathrm{NH}_{4}\right)$ concentration levels from the oxidation of organic- $\mathrm{N}$ which is dissociated to $\mathrm{NH}_{4}, \mathrm{NO}_{2}$, and $\mathrm{NO}_{3}$, respectively. The results indicated that nitrate concentration in the first four wells were below pollution limits while it was very high in the remaining well (127-133 mg/L), rendering water from this well undrinkable (Eryurt and Sekin 2001). In addition, although nitrite and nitrate in groundwater around Manisa region were detected in all wells, they were below the drinking water standards (Eryurt and Sekin 2001). The main sources of nitrite and nitrate in groundwater around Manisa region are fertilizers used in agricultural activities. When organic fertilizers are used for agricultural activities, nitrite and nitrate can be formed and washed out from soil to groundwater due to bacterial metabolic activities (Eryurt and Sekin 2001). Agricultural related pollution of groundwater also occurs in the Eskişehir plain (Kaçaroğlu and Günay 1997) and between Mersin and Tarsus (Kurt et al. 2009).

Erdoğan and Karaca (2001) reported that pesticide consumption was $9.9 \mathrm{~kg} / \mathrm{ha}$, the types of pesticides are increased, and 102 different types of pesticides were used in agricultural areas in the Göksu Delta, Mersin. Additionally, the amount of fertilizers was 7,200 tons in 2006. These pollutants affect the surface and groundwater quality negatively in this region (Demirel et al. 2011).

According to Karadavut et al. (1997), excessive use of nitrate fertilizers for potato production has caused adverse effects on groundwater in and around the city of Niğde (Fig. 1). It should be noted that phosphate fertilizers contain heavy metals (Haktanır 1992). Similar contamination problems have occurred around the Çukurova (Adana) and Amik (Hatay) plains (Fig. 1).

Groundwater contamination by pesticides has become an important environmental issue. Aydın and Yurdun (1999) examined nine different chlorinated pesticides in the water sources and tap water of İstanbul, Turkey. They observed organochlorine pesticides which were $\alpha$ - and $\gamma-\mathrm{HCH}$ and aldrin; both are banned from use. $\alpha$ - and $\gamma-\mathrm{HCH}$ contents in raw waters were in the range of 0.341.7 and $0.077 \mathrm{ppb}$, respectively; $0.03 \mathrm{ppb}$ aldrin 
was observed in some samples. Residue levels of organochlorine pesticides in the drinking water supplies in Istanbul were found to be significantly under the maximum permissible levels. It was noted that potable water treatment processes and maintenance and backwashing of sand filters are very effective in pesticide removal. Improper and delayed backwashing of filters has caused an increase in the pesticide residues in the distributed water. In aging water distribution lines, high concentrations of some organochlorines were also observed (Baba and Ayyıldız 2006; Aydın and Yurdun 1999).

Özler and Aydin (2008) found that microbiological and chemical values in groundwater exceed the drinking water limit in Western Thrace region. The existence of indicator bacteria in high amounts in microbiological analyses may indicate that there may be other pathogen bacteria.

\section{Industrial wastes}

Locating industrial facilities on or around plains in many Turkish regions and discharging untreated wastewaters into aquifers has resulted in serious pollution. Groundwater contamination has been observed in and around the Gulf of İzmir within the borders of the city of Izmir. This contamination has arisen due to improper discharge of groundwater and the rapid development of industry. In the Bostanlı, Karşıyaka, Sahilevleri, and Alsancak regions (İzmir), groundwater levels were observed to be unusually high with soils containing a high concentration of organic matters (Baba et al. 2001; Baba and Ayyıldız 2006). Also, groundwater qualities have been affected by petroleum hydrocarbon around Mersin where petrochemical industrial activities are very intense. Total of 215 wells were monitored in this region. The result show that highly contaminated parts of the area dissolved oxygen concentration range between 0.48 and $2.38 \mathrm{mg} / \mathrm{L}$ and $\mathrm{pH}$ values between 6.87 and 7.6. In comparison to pollutionfree parts of the aquifer, in contaminated parts, dissolved oxygen and $\mathrm{pH}$ generally display lower values (Güler et al. 2009).

Yüce (2006) studied the vulnerability of groundwater in the Porsuk River (Eskişehir) Basin. This study showed that the $\mathrm{NH}_{3}$, oil and grease, chemical oxygen demand, biochemical oxygen demand, phenolic material, free chlorine, and sulfur values of Porsuk River have increased compared to those of previous years and become worse with the wastewater loadings from the sugar factory and large industrial estate.

There are many factories in Torbalı, İzmir, nearly all of which had discharged their wastewaters into Fetrek Creek up until April 2002. The waste disposal site of the region, which is near a farm, has not been designed properly, so contaminants may have been infiltrating into the groundwater (Tayfur et al. 2008; Şimşek et al. 2008).

\section{Mining activity}

Several abandoned mercury mines are located in western Turkey, such as Alaşehir (Manisa) and Türkönü (İzmir; Gemici 2008). Due to low prices, low demand, and increasing environmental concerns about mercury, the mines were gradually abandoned until the last one closed in the early 1990s (Gemici and Oyman 2003). The acid drainage and mine wastes create potential environmental problems around these mines. With a characteristic reddish yellow color, low $\mathrm{pH}$ value, and high metal and toxic element content, acidic mining lakes are known to contaminate regional drinking water supplies and to disrupt the growth and reproduction of surrounding aquatic life. A number of such lakes have been formed within the last decade in Çan (Çanakkale) coal basin (Fig. 1). In addition, the abandoned small-tomedium-scale open-pit coal mines in Canakkale region were found to be responsible from the formation of several mining lakes that were inundated as a result of surface drainage as well as subsurface infiltration to depression areas of the open pit. These lakes were later transformed into acidic mining lakes due to the oxidation of pyrite found in the coal. With very high acidity levels ( $\mathrm{pH}$ levels as low as 2 to 3 ) and high trace element contents (with maximum aluminum and iron levels of 211 and $528 \mathrm{ppm}$ ), these lakes were found to influence the quality of local water resources in the area (Gündüz et al. 2007; Baba and Gündüz 2009).

Aykol et al. (2003) revealed that, in the Balya region in the province of Balıkesir (Fig. 1), 
rainfall induced runoff from lead mining wastes flows into the River Kocaçay and creates a serious environmental pollution. Studies carried out in the region have also indicated that groundwater have acidic characteristics due to mining activities. Aykol et al. (2003) also investigated the effects of the waste rock dump (WRD) of the underground polymetallic Balya Mine on the Kocaçay River and Lake Manyas. They examined the geochemical characteristics of various kinds of water (mine, surface, and groundwater) and analyzed some suspended-particle samples. The results showed that polluted mine waters have low $\mathrm{pH}$ and high conductivity. High concentrations of $\mathrm{Zn}, \mathrm{Cd}$, and $\mathrm{Mn}$ tend to be found in both the dry and wet seasons while high concentrations of $\mathrm{Pb}, \mathrm{As}, \mathrm{Cr}$, $\mathrm{Cu}$, and $\mathrm{S}$ appear only in the wet season. The sources of the heavy metal concentration within the River Kocaçay are from the leached waste, surface runoff, and overflow from the spillway of the WRD (Aykol et al. 2003).

A hydrochemical study of the area surrounding the Hisarcik (Emet-Kütahya; Fig. 1) colemanite mine shows extremely high arsenic contamination in groundwater, with concentrations ranging between 0.07 and $7.754 \mathrm{mg} \mathrm{L}^{-1}$. This contamination in and around the İğdekoy village of Emet was caused by naturally occurring arsenic dissolution from a borate bearing clay zone due to the leaching of arsenic bearing minerals. The arsenic concentration in the groundwater varies locally from spring to spring and is related to the mineralogical and geochemical composition and lithofacies of the aquifer (Çolak et al. 2003).

Borate minerals are produced in a limited number of countries dominated by the USA and Turkey, which together furnish about $90 \%$ of the world's borate supplies (Helvacı 2005). Bigadiç (Fig. 1) borate deposits are among the largest colemanite and ulexite deposits in the world. Borate-bearing formations have affected the concentrations of some contaminants in groundwater. Groundwater quality is directly related to the borate zones in the mines as a result of water-rock interaction processes (Yazıcigil et al. 2009). Boron and arsenic were the two important contaminants determined in the groundwater around the Bigadiç borate mines in Turkey. Arsenic is the major pollutant, and it ranged from 33 to $911 \mu \mathrm{g} / \mathrm{L}$ in the groundwater samples. The concentrations of $\mathrm{B}$ in the study area ranged from 0.05 to $391 \mathrm{mg} / \mathrm{L}$. The highest B concentrations were detected at the mine near the mining areas. The extension of the borate zones in the aquifer is the essential factor in the enrichment of B and As, and some major and trace elements in groundwater are directly related to the leaching of the host rock, which is mainly composed of tuffs and limestone (Gemici et al. 2008). Heavy metals such as copper, chromium, lead, cobalt, nickel, and zinc from mining processes in Elazığ (Fig. 1) have also been polluting the Tigris River (Çetindağ and Okan 2004).

Since significant urban development is already taking place on the geological units that contain gold ore bodies in Turkey, studying the adverse affects of mine processing on the environment is extremely important. Such an area is located on the southeastern part of İzmir where about 2-kmlong gold-bearing ore veins exist close to the village of Efemçukuru. The gold-bearing formation is highly weathered and fractured. The fractures in the geological units control the permeability and groundwater level in the area (Baba and Güngör 2002; Baba and Ayyıldız 2006).

Arsenic is one of the major pollutants around Simav (Kütahya; Fig. 1). Arsenic values reach $305 \mu \mathrm{g} / \mathrm{L}$ in groundwater. Also, the average B concentration is around $35 \mathrm{mg} / \mathrm{L}$ for groundwater samples (Gemici et al. 2008). These values are greater than the safe levels for drinking and irrigation.

Çan region (Çanakkale; Fig. 1) is rich in clay mines and lignite deposits. The results of a study of major anion, cation, and some trace elements in groundwater and surface water around the Çan region showed that groundwater is very rich in $\mathrm{Ca}-\mathrm{Mg}-\mathrm{SO}_{4}$. Al concentrations are more than the acceptable maximum standard value (Baba et al. 2007).

Coal-burning power plants in Turkey produce large quantities of coal-related wastes, which are collected through the use of various systems. When coal is burned, loss of material causes in an increased concentration of mostly heavy metals and radionuclides in the waste material. The waste 
disposal site near the Yatağan (Muğla) Thermal Power Plant contains a major enhancement of heavy metals and radioactivity which affects groundwater (Baba 2002, 2003). Water leaches through the waste hills at Yatağan and into karstic marbles overlying schist adversely affect the quality of groundwater and surface waters (Baba et al. 2003).

In 1997, due to the improper wet disposal site in the Seyitömer power plant in Kütahya, ash flow occurred over agricultural fields. Güleç et al. (2001) reported that $\mathrm{Cr}$ and Co released from the Seyitömer Power Plant were very high exceeding regulatory standards for drinking water and irrigation. Uğurlu (2004) examined the leaching behavior of fly ashes currently disposed in the Kemerköy Power Plant (Muğla) fly-ash-holding pond (Fig. 1). The $\mathrm{Ca}$ and $\mathrm{Mn}$ concentrations decrease while $\mathrm{Na}$ and $\mathrm{K}$ concentrations increase with increasing temperature. The results showed that the most important effects of fly ash leaching were $\mathrm{pH}, \mathrm{Na}, \mathrm{Ca}, \mathrm{K}, \mathrm{Fe}, \mathrm{Mg}, \mathrm{Mn}$, and $\mathrm{Pb}$. In particular, use of low quality coal with high ash content results in huge quantities of fly ash deposition. Ugurlu (2004) indicated that the main problem related to fly ash disposal was the residue heavy metal content. Numerous experimental studies show that toxic trace metals can be leached from fly ash (Georgakopoulos et al. 2002; Baba and Kaya 2004; Baba and Ayyıldız 2006; Burcu et al. 1997; Campbell et al. 1978; Davison et al. 1974; Gehrs et al. 1979; Hulett et al. 1980; Hansen and Fisher 1980; Klein et al. 1975).

The impact of quarries on the environment and particularly on the groundwater system in terms of quality and quantity has often been ignored until the last few decades. Regardless of the amount of quarried rock which may be quite small compared to the volume of an outcrop, the result of removing the protective cover of an aquifer may cause severe pollution of the groundwater (Ekmekçi 1993).

\section{Septic tank systems}

Groundwater contamination due to past surface waste disposal operations is a serious and common problem in aquifers that are developed to supply drinking water requirements in many countries (Misirlı et al. 1995). In Turkey, there are presently increasing number of many abandoned and uncontrolled waste sites. These wastes can eventually make their way down into the groundwater as a result of leaching. Kaçaroğlu and Günay (1997) and Yüce (2007) studied the groundwater pollution in Eskişehir Plain, an urbanized area. They reported that the groundwater in the alluvium aquifer of the Eskisehir Plain is polluted by wastewaters transported through Porsuk River, agricultural-industrial activities, rivergroundwater interactions, and unsanitary landfill. Porsuk River flows throughout the alluvium aquifer in the Plain. In the period of July 1986August 1988, the nitrate concentrations at nine sampling points on the River Porsuk, which is the main watercourse in the plain, ranged from 1.5 to $63 \mathrm{mg} / \mathrm{L}$. The nitrate concentrations measured from 51 wells in the alluvium ranged between 2.2 and $257 \mathrm{mg} / \mathrm{L}$ in the same period. The nitrate content in $34.2 \%$ of the groundwater samples was above $45 \mathrm{mg} / \mathrm{L}$, which is the according to drinking water standards in Turkey. According to these studies, groundwater in the Eskisehir Plain is in a poor quality both for drinking and domestic purposes.

Karagüzel and Irlayici (1998) revealed that sewage water in the city canals and waste storage are the largest polluters in the Isparta Plain. They concluded that almost two thirds of the aquifer in the plain was severely polluted. The groundwater at shallow depths in the alluvium, which is composed of gravel, sand, and clay, is expected to be more contaminated under and around the open waste disposal site where both household and industrial wastes are improperly deposited. In another study, Karagüzel et al. (1999) showed that groundwater of an aquifer in Antalya, which is an urbanized city (Fig. 1), was contaminated by sewage discharge, industrial works, and other activities.

Öztaş (1997) studied the groundwater contamination around the Bakırkoy Basin catchments (İstanbul). He concluded that groundwater in the catchments is severely polluted due to leakage water from domestic septic tank systems. Similarly, Öztaş (1997) reported that groundwater is 
also seriously contaminated at the northern part of the Küçükçekmece Lake in İstanbul due to the presence of septic tank wastes (Baba and Ayyıldız 2006).

In the Büyük Menderes Valley, the groundwater is heavily contaminated because of continuous discharge of untreated domestic sewage waters into the river (Karamenderesi and Helvaci 2001). Due to rapid population rise and urbanization in the region, water consumption is increasing. Such excessive water consumption would probably lead to more serious environmental problems in the near future (Baba and Ayyıldız 2006).

At the Gölbaşı waste disposal site, located around a small stream valley in Ankara, sewage water is directly discharged into the stream. This has led to the significant groundwater contamination in the region (Canpolat et al. 1997; Çelik et al. 2007). Furthermore, toxic elements, released from the disposal sites, are carried to Lake Eymir through groundwater flow. Also, Mamak solid waste, an old waste disposal site at Mamak, Ankara, has been effected groundwater resources that hydrochemical facies shifts from $\mathrm{Na}^{+}-\mathrm{Cl}^{-}$to $\mathrm{Ca}^{2+}-\mathrm{HCO}_{3}^{-}$(Çelik et al. 2007).

Disposing of industrial and domestic wastes onto karstic environments can pose a particular danger for groundwater. The ongoing development of karst aquifers, especially in the southern part of Turkey, demonstrates specific environmental problems occurring in many karst water supply projects (Elhatip 1997; Elhatip and Günay 1998). Karst aquifers have specific hydraulic and hydrogeological characteristics that render them highly vulnerable to pollution from human activities. Karst groundwater becomes polluted more easily and quickly than water in non-karstic aquifers (Kaçaroğlu 1999). Scarcity of water, particularly in towns situated along the Mediterranean coast where the main aquifers are in karstic region, necessitates more thoroughness in exploiting and protecting the groundwater resources. Recharge areas tend to be located at higher elevations and in regions remote from urbanized areas. Dolines and ponors are commonly utilized as injection points for wastewater, while uvalas and poljes are used as solid waste disposal sites. When doing this, the people are unaware of the connection of such sites with the wells or springs that provide water for their supply (Ekmekçi and Günay 1997; Baba and Ayyıldız 2006).

The large Kestel polje (Antalya) is $40 \mathrm{~km}$ from the springs and within the recharge area of the system. Utilization of the Kestel polje for agriculture as well as sewage disposal at sinkholes is a source of pollution. Water samples were analyzed for nutrients and some of the pesticides were found among the persistent organic pollutants (Ekmekçi 2005).

İznik marble and alluvium units constitute the main aquifer system in the İznik region (Bursa). Because of the İznik marble has highly fractural features, the wastewater in the quarries moved rapidly within rock. It was observed that the groundwater level changed roughly between 5 and $17 \mathrm{~m}$ and that the general ground flow direction was north. Sewage in the ancient quarries moved quickly through the fracture zone and affected the groundwater quality near the waste site (Şimşek et al. 2009).

\section{Groundwater contamination and health effects}

Geological sources of arsenic within their environmental setting and the dermatological impact have been investigated in Emet (Kütahya) region. A total of 153 individuals were screened from Dulkadir and Ignekoy villages in Emet. An apparent dose-response relationship between consumption of arsenic contaminated drinking water and skin disorders was observed. People from Dulkadir where the water contained $0.3-0.5 \mathrm{mg}$ As per liter had fewer lesions than those from Igdekoy with 8.9-9.3 $\mathrm{mg}$ as per liter. At Igdekoy $30.9 \%$ of individuals had arsenic-related skin disorders compared to $5.35 \%$ in Dulkadir (Dogan et al. 2005). In addition, blood and hair samples were obtained from 30 village inhabitants who were exposed to arsenic in groundwater. The result shows that exposure to arsenic in drinking water causes serious DNA damage in this region (Şardaş 2009).

Fluoride in water is mostly of geological origin. Waters with high levels of fluoride content are mostly found in volcanic rocks and geothermal fluid(s) in Turkey. Ingestion of excess fluoride, most common in drinking water in different 
part of Turkey, can cause fluorosis which affects the teeth and bones. Low amounts can lead to dental defects, but long-term ingestion of large amounts can lead to potentially severe skeletal problems (Demirel 2008a). The control of drinking water quality is therefore critical in preventing fluorosis. According to some documents and also the United Nations Development Programme, fluorosis is still a (major) health problem in Turkey, which has numerous thermal springs and youthful volcanic features. For example, geothermal water sources in the villages of Ortakçı and Ericek in Buharkent district of Aydın province-involving main thermal water locations-are cooled to the appropriate temperature by mixing with fresh cold drinking water. There is a significant dental fluorosis problem in these areas. Also, the endemic fluorosis occurrences have been determined in Eskişehir, Beylikova, and Kızılcaören (Demirel 2009).

Isparta city is localized on such a volcanic area, and Gölcuk Crater Lake is one of the water sources of the city. Endemic dental and skeletal fluorosis was first observed in Turkey in Isparta about 55 years ago. The origin of fluoride was attributed to the mineral content in volcanic rocks (Demirel 2008a). Another geothermal location, Denizli province-Sarayköy district, was named as having a suspected fluorosis problem in an international report (WHO 2006). Thirtyfive years ago, severe dental and skeletal fluorosis was observed in human beings and livestock in Doğubeyazıt and Çaldıran areas, located around Tendürek Volcano in eastern Turkey, where natural waters contained fluoride levels between 2.5 and 12.5 ppm (Demirel 2008b).

Alzheimer is a common illness. Generally, it is diagnosed in people over 65 years of age (Brookmeyer et al. 1998). A number of environmental factors have been put forward as possible contributory causes of Alzheimer disease in some people. Among these is aluminum. Some water sources in Turkey contain too much aluminum. For example, water from Kirazlı (Çanakkale) contains aluminum levels between 13 and 16 ppm (Baba and Deniz 2008). Many people have undergone medical treatment in this region. It appears that local people have been affected by water sources coming from densely altered volcanic rocks. A to- tal of 273 people aged above 18 years and inhabit in this region were selected as the research group. The result showed that neuropathy in the history was significantly higher in Kirazli Region (Bakar et al. 2010).

Iodine is an important trace element for human health. It is a distinctive component of thyroid hormones and plays an important role in growth and development. Since the 1960s, Turkey has been recognized as an area of iodine deficiency. A mild to severe degree of iodine deficiency has been detected in settlements along the west coast of Turkey. Generally, water sources have low iodine content in some parts of Turkey. A total of 76 drinking water samples from rural and urban areas in the Aegean region of Turkey were analyzed. The mean iodine concentration was $78 \pm 27 \mu \mathrm{g} / \mathrm{L}$, and iodine concentration ranges were within $69 \pm 26 \mu \mathrm{g} / \mathrm{L}$ and $103 \pm 6 \mu \mathrm{g} / \mathrm{L}$ (Ünak et al. 2007).

In addition, low water quality may cause waterborne diseases. One of the most important among these is the investigation of the relationship between high radon content in drinking water and lung cancer. Therefore, radon concentrations were measured in water resources around Eskisehir where there is higher natural radioactivity due to regional resources. The results show that radon content in most of water resources is higher than the normal value according to $\mathrm{WHO}$ and $\mathrm{EU}$ standards (Yüce et al. 2009)

\section{Summary and conclusion}

The geological sources of contamination which mostly releases arsenic into groundwater are mostly located around Aegean region. TDS, calcium, and sulfate contamination due to salt and gypsum are mostly found in Central and Mediterranean regions.

The quality of surface waters also can contaminate groundwater by infiltration. Such contamination resulting in high concentrations of $\mathrm{Mn}$, $\mathrm{Fe}, \mathrm{Zn}$, etc. are found in Upper Kizılırmak basin, Gediz basin, and Büyük Melen river basin and some drinking water reservoirs of İstanbul.

Seawater intrusion causes groundwater quality problems in coastal regions, especially in the 
Aegean coast. It raises the concentrations levels of $\mathrm{Na}, \mathrm{Mg}, \mathrm{Ca}$, and $\mathrm{HCO}_{3}$ in groundwater.

Another major problem is the contamination due to geothermal fluids, especially from the geothermal fields in Aegean region, releasing concentrations of heavy metals, especially $\mathrm{B}$, fatal to living beings in this region. It not only contaminates groundwater but also major rivers such as Büyük Menderes and Gediz in this region.

Industrial wastes are also polluting surface and groundwater in the industrialized regions such as İzmit and İzmir bays, Torbalı region of İzmir, Gediz, Kizılırmak, and Porsuk rivers. It is important to carry out toxicity tests in wastewater discharge regulations to control this pollution.

Deterioration of water quality as a result of fertilizers and pesticides is another major problem in Turkey, especially in the regions of Mediterranean, Aegean, Central Anatolia, and Marmara. Due to heavy fertilization, nitrate and nitrite contamination is very common in this region where the levels are above the standards.

Abandoned mercury mines, lead mining, colemanite mine, gold mining, and lignite mining, in the regions of western Turkey, especially in Çanakkale, İzmir, Muğla, Kütahya, and Balıkesir, cause serious groundwater quality problems by raising concentration levels of arsenic, boron, $\mathrm{Ca}, \mathrm{Mg}, \mathrm{Al}, \mathrm{SO}_{4}, \mathrm{Cu}, \mathrm{Cr}, \mathrm{Co} \mathrm{Ni}, \mathrm{Zn}$, and $\mathrm{Mn}$. In addition, coal burning power plants located mostly in the Aegean region cause pollution by their disposal sites and fly ash.

Surface and groundwater around metropolitan areas, such as İstanbul, Bursa, İzmir, Ankara, Antalya, and Eskişehir, are also contaminated by improperly constructed municipal and industrial waste sites. The unexpected seepage from these sites as a result of rainfall-runoff carries with it heavy metals, thus causing major pollution.

Young volcanic rocks and geothermal fluids which contain fluoride pose a danger for skeleton, dental, and bone problems, especially in the areas of Denizli, Isparta, and Aydın. Excess levels of $\mathrm{Al}$ in drinking water as a result of mining sites cause Alzheimer disease in and around Aegean region, especially in Çanakkale. A mild to severe degree of iodine deficiency which is fundamental for growth and development exists in settlements along the west coast of Turkey.
Groundwater quality is supremely important for people's health. In recent years, there has been a significant growth of interest in environmental issues, including groundwater quality, within our country. This brings with it an enormous social responsibility to sustain and safeguard our environment by monitoring and solving risk factors that may be potentially threatening the health. Therefore, a comprehensive protection and control system must be developed, including the establishment of a groundwater monitoring system, the delineation of critical protection zones, and the control and elimination of sources of pollution. In addition, increasing the public awareness on the value and vulnerability of aquifers in Turkey is fundamental.

\section{References}

Afşin, M. (1997). Hydrochemical evolution and water quality along the groundwater flow path in the Sandikli Plain, Afyon, Turkey. Environmental Geology, 31(3-4), 221-230.

Aslan, G., \& Akkaya, C. (2001). Basic problems in groundwater sources and interactions between surface and groundwater. In Groundwaters and environment symposium (pp. 45-54). Izmir, 21-23 March.

Aslan, S., Turkman, A., Ovez, B., Yuksel, M., \& Alyanak, I. (2001). Investigating groundwater pollution around Urla and Menemen in the Aegean Region. In Groundwaters and environment symposium (pp. 125-131). Izmir, 21-23 March.

Aydın, A., \& Yurdun, T. (1999). Residues of organochlorine pesticides in water sources of Istanbul. Water, Air, and Soil Pollution, 111(1-4), 385-398.

Aykol, A., Budakoglu, M., Kumral, M., Gultekin, A. H., Turhan, M., Esenli, V., et al. (2003). Heavy metal pollution and acid drainage from the abandoned Balya $\mathrm{Pb}-\mathrm{Zn}$ Sulfide Mine, NW Anatolia, Turkey. Environmental Geology, 45(2), 198-208.

Baba, A. (2002). Assessment of radioactive contaminants in by-products from Yatagan (Mugla, Turkey) coalfired power plant. Environmental Geology, 41(8), 916-921.

Baba, A. (2003). Geochemical assessment of environmental effects of ash from Yatagan (Mugla-Turkey) thermal power plant. Water, Air, and Soil Pollution, 144(1-4), 3-18.

Baba, A. (2004). Geothermal environmental impact assessment with special reference to the Tuzla, geothermal area, Canakkale Turkey (pp. 75-114). Iceland: Geothermal Training Programme.

Baba, A. (2010). High arsenic levels in water resources resulting from alteration zones: A case study from Biga Peninsula, Turkey. In AS2010, 3rd international 
congress: Arsenic in the environment (pp. 8-20). Tainan, Taiwan, 17-21 May.

Baba, A., \& Ármannsson, H. (2006). Environmental impact of the utilization of a geothermal area in Turkey. Energy Source, 1, 267-278.

Baba, A., \& Ayyıldız, O. (2006). Urban groundwater pollution in Turkey, a national review of urban groundwater quality issues. In J. H. Tellam, et al. (Eds.), Urban groundwater management and sustainability, IV. Earth and environmental sciences, NATO science series (pp. 93-110). New York: Springer.

Baba, A., Birsoy, Y. K., Ensari, E., Andic, T., \& Baykul, A. (2001). Izmir City's groundwater quality and pollution. In Groundwaters and environment symposium (pp. 149-158). Izmir, 21-23 March.

Baba, A., \& Deniz, O. (2004). The impact of open waste disposal site on surface and groundwater and investigation of groundwater quality of Canakkale City (p. 74). Canakkale Onsekiz Mart University. Project number: 2001-b/04.

Baba, A., \& Deniz, O. (2008). Potential, determination of applicability and evaluation of environmental effects of geothermal source in the Biga Peninsula, TUBITAK prj (p. 349). Project no: 104Y082, Ankara.

Baba, A., Deniz, O., \& Gülen, O. (2007). Effects of mining activities on water around the Çanakkale Plain, Turkey. In Wastewater reuse-risk assessment, decisionmaking and environmental security, NATO security through science series (pp. 3-10). The Netherlands: Springer.

Baba, A., \& Gündüz, O. (2009). Environmental factors that influence the water resources of Northwestern Ida Mountains (Çanakkale-Turkey). In 62nd Geological Kurultai of Turkey (p. 145). Ankara, Turkey, 13-17 April.

Baba, A., \& Güngör, T. (2002). Influence of gold mine on groundwater quality (Efemçukuru, Izmir, Turkey). Environmental Geology, 41(6), 621-627.

Baba, A., \& Kaya, A. (2004). Leaching characteristics of fly ash from thermal power plants of Soma and Tunçbilek, Turkey. Environmental Monitoring and Assessment, 91(1-3), 171-181.

Baba, A., Kaya, A., \& Birsoy, Y. K. (2003). The effect of Yatagan thermal power plant (Mugla, Turkey) on the quality of surface and groundwaters. Water, Air, and Soil Pollution, 149(1-4), 93-111.

Baba, A., Özcan, H., \& Deniz, O. (2005). Environmental impact by spill of geothermal fluids at the geothermal field of Tuzla, Canakkale-Turkey. In Proceedings World Geothermal Congress 2005 (pp. 1-8). Antalya, Turkey, 24-29 April.

Baba, A., \& Yiğitbas, E. (2007). Hydrology and hydrogeochemistry of Kavak Plain (Bodrum-Muğla) (pp. 1-34). COMU Project (unpublished), Canakkale, Turkey.

Bakar, C., Karaman, H. I. Ö., Baba, A., \& Şengünalp, F. (2010). Effect of high aluminum concentration in water resources on human health, case study: Biga Peninsula, Northwest part of Turkey. Archives of Environmental Contamination and Toxicology, 58(4), 935-944.

Bozkurt, E. (2001). Neotectonics of Turkey-A synthesis. Geodinamica Acta, 14, 3-30.
Brookmeyer, R., Gray, S., \& Kawas, C. (1998). Projections of Alzheimer's disease in the United States and the public health impact of delaying disease onset. American Journal of Public Health, 88(9), 1337-42.

Burak, S., Duranyilmaz, I., \& Yetis, U. (1997). National environment protest plan, management of water resources. Ankara: Turkish General Directorate of State Hydraulic Works (DSI).

Burcu, Ç., Güleç, N., \& Erler, A. (1997). Geochemical assessment of environmental effects of fly ash-From Seyitomer (Kutahya) power plant. In I. Yilmazer (Ed.), Proceedings of the international symposium on geology and environment (pp. 9-17). Istanbul, Turkey, 1-5 September.

Campbell, J. A., Laul, J. C., Neilson, K. K., \& Smith, R. D. (1978). Separation and chemical characterisation of finely sized fly ash particles. Analytical Chemistry, 50(8), 1032-1040.

Canpolat, F., Çamur, M. Z., \& Yazıcıgil, H. (1997). Hydrogeochemistry of groundwaters at Gölbaşı waste disposal area: Preliminary investigations. Geological Engineering, Turkish Chamber of Geological Engineers, 50, 47-51.

Cech, V. T. (2003). Principles of water resources-History, development, management, and policy (p. 446). USA: Wiley.

Çelik, M., Tastekin, M., \& Kayabali, K. (2007). An investigation of the surface and groundwater leachate from an old waste disposal site at Mamak, Ankara, Turkey. International Journal of Environment and Pollution, 30(3-4), 548-560.

Çelik, M., \& Yıldırım, T. (2006). Hydrochemical evaluation of groundwater quality in the Çavuşçayı basin, Sungurlu-Çorum, Turkey. Environmental Geology, 50(3), 323-330.

Çetindağ, B., \& Okan, Ö. (2004). Hydrochemical characteristics and pollution potential of Uluova aquifers, Elazı̆̆, Turkey. Environmental Geology, 45(6), 796807.

Çolak, M., Gemici, U., \& Tarcan, G. (2003). The effects of colemanite deposits on the arsenic concentrations of soil and groundwater in Igdeköy-Emet, Kütahya, Turkey. Water, Air, and Soil Pollution, 149(1-4), 127-143.

Davison, R. L., Natusch, D. F. S., Wallace, J. R., \& Evans, C. A., Jr. (1974). Trace elements in fly ash: Dependence of concentration on particle size. Environmental Science \& Technology, 8(13), 1107-1112.

Değirmenci, M., \& Altın, A. (2001). Investigating salinisation of groundwater around sea coastlines between Mersin and Erdemli. In Groundwater and environment symposium, 21-23 March 2001 (pp. 173-183).

Demirel, U. (2008a). Fluoride-Fluorosis in Turkey-A dilemma. In Fluorosis congress in Toronto, Canada (pp. 1-2).

Demirel, U. (2008b). Fluoride-Fluorosis problem in thermal water land in Turkey, mineral water workshop (pp. 235-236). Istanbul: Department of Geological Engineering, Istanbul Technical University.

Demirel, U. (2009). The effect of fluoride on human and fluorosis problem in Capadocia Region, 1 (pp. 127- 
137). Tıbbi Jeoloji Çalıştayı, 30 Ekim-1 Kasım 2009, Ürgüp, Nevşehir, Turkey.

Demirel, D., Özer, O., \& Özpınar, Z. (2011). Investigation of groundwater pollution in a protected area in Turkey, the Göksu Delta. G.U. Journal of Science, 24(1), 17-27.

Demirel, Z. (2004). The history and evaluation of saltwater intrusion into a coastal aquifer in Mersin, Turkey. Journal of Environmental Management, 70(3), 275-282.

Dewey, J. F., \& Şengör, A. M. C. (1979). Aegean and surrounding regions: Complex multiplate and continuum tectonics in a convergent zone. Geological Society of America Bulletin Part I, 90, 84-92.

Dogan, M., Dogan, A. U., Celebic, C., \& Baris, Y. I. (2005). Geogenic arsenic and a survey of skin lesions in the Emet Region of Kutahya, Turkey. Indoor and Built Environment, 14(6), 533-536.

Doğdu, M. Ş., \& Bayarı, C. S. (2002). Pollution of geothermal origin in the Akarçay Basin (Afyon, Turkey): 2. Groundwater pollution. Yerbilimleri, 25, 35-49.

DSİ (2010). General directorate of state hydraulic works. http://www.dsi.gov.tr.

Ekmekçi, M. (1993). Hydrogeological processes in karst terrenes. In Proceedings of the Antalya symposium and field seminar, October 1990. IAHS publ., no: 207.

Ekmekçi, M. (2005). Pesticide and nutrient contamination in the Kestel polje-Kirkgoz karst springs, Southern Turkey. Environmental Geology, 49, 19-29.

Ekmekçi, M., \& Günay, G. (1997). Role of public awareness in groundwater protection. Environmental Geology, 30(1-2), 81-87.

Elhatip, H. (1997). The influence of karst features on environmental studies in Turkey. Environmental Geology, 31(1-2), 27-33.

Elhatip, H., \& Günay, G. (1998). Karst hydrogeology of the Kaş-Kalkan springs along the Mediterranean Coast of Turkey. Environmental Geology, 36(1-2), 150-158.

Elhatip, H., Afsin, M., Kuscu, İ., Dirik, K., Kurmac, Y., \& Kavurmaci, M. (2003). Influences of human activities and agriculture on groundwater quality of Kayseriİncesu-Dokuzpınar springs, Central Anatolian Part of Turkey. Environmental Geology, 44(4), 490-494.

Emekli, N., Karahanoğlu, N., Yazicigil, H., \& Doyuran, V. (1996). Numerical simulation of saltwater intrusion in a groundwater basin page. Water Environment Research, 68(5), 855-866.

Erdoğan, B., \& Karaca, I. (2001). Mersin special environment protection report (pp. 1-18). Mersin, Turkey.

Eroskay, O., \& Günay, G. (1979). Tecto-genetic classification and hydrogeological properties of the karst region in Turkey. In International seminar on Karst hydrogeology-proceeding, DSI-UNDP project (p. 385). DSI Ankara, Turkey.

Eryurt, A., \& Sekin, Y. (2001). Seasonal changes in groundwaters around Manisa Region, hardness and nitrated compounds. In Groundwater and environment symposium (pp. 187-193). Izmir, 21-23 March.

Fidanci, U. R. (1997). Floroizs. In Water and environment symposium proceedings (pp. 184-194). Istanbul, 2-5 June.
Fidanci, U. R., Bayşu, N., \& Ergun, H. (1994). The fluoride content of water sources in Kizılcaören Village in Eskisehir, Tr. Journal of Medical Science, 20, 15-17.

Filiz, S., Tarcan, G., \& Gemici, U. (1998). Hydrogeological and hydrogeochemical study of the Bodrum and its vicinity. In Firat University, Geology Engineering's 20th anniversary symposium (pp. 579-594).

Gehrs, C. W., Shriner, D. S., \& Herbes, S. E. (1979). Environmental health and safety implications of increased coal utilization. In M. A. Elliot (Ed.), Chemistry of coal utilization, second supplementary volume (pp. 2194-2219).

Gemici, Ü. (2004). Impact of acid mine drainage from the abandoned Halıköy mercury mine (western Turkey) on surface and groundwaters. Bulletin of Environmental Contamination and Toxicology, 72, 482-489.

Gemici, Ü. (2008). Evaluation of the water quality related to the acid mine drainage of an abandoned mercury mine (Alaşehir, Turkey). Environmental Monitoring and Assessment, 147, 93-106.

Gemici, Ü., \& Filiz, S. (2001). Seawater intrusion around coastlines aquifers in Cesme Peninsula (Izmir). In Groundwaters and environment symposium (pp. 195203). Izmir, 21-23 March.

Gemici, Ü., \& Oyman, T. (2003). The influence of the abandoned Kalecik $\mathrm{Hg}$ mine on waters and stream sediments, (Karaburun, İzmir, Turkey). The Science of the Total Environment, 312, 155-166.

Gemici, Ü., \& Tarcan, G. (2002). Distribution of boron in thermal waters of Western Anatolia, Turkey, and examples on their environmental impacts. Environmental Geology, 43, 87-98.

Gemici, Ü., \& Tarcan, G. (2007). Assessment of the pollutants in farming soils and waters around untreated abandoned Türkönü mercury mine (Turkey). Bulletin of Environmental Contamination and Toxicology, 79, 20-24.

Gemici, Ü., Tarcan, G., Helvaci, C., \& Somay, A. M. (2008). High arsenic and boron concentrations in groundwaters related to mining activity in the Bigadic borate deposits (Western Turkey). Applied Geochemistry, 23, 2462-2476.

Georgakopoulos, A., Filippidis, A., Fournarakı, A. K., Iordanidis, A., Turiel, J. L. F., Llorens, J. F., et al. (2002). Environmentally important elements in fly ashes and their leachates of the power stations of Greece. Energy Source, 24, 83-91.

Güleç, N., Canci, B. G., \& Erler, A. (2001). Assessment of soil and water contamination around an ash-disposal site: A case study from the Seyitömer coal-fired power plant in Western Turkey. Environmental Geology, 40(3), 331-344.

Güler, C., Akabulut, C., \& Kurt, M. A. (2009). Characterization of petroleum pollution and ground water physical properties in the Karaduvar (Mersin) coastal aquifer. In 62nd Geological Kurultai of Turkey (p. 133). Ankara, Turkey, 13-17 April.

Gündüz, O. (2009). Kütahya- Simav ovasinda arsenic sorunu: Mevcut durum ve yeni araştırmalar, 1 (pp. 127137). Tıbbi Jeoloji Çalıştayı, 30 Ekim-1 Kasım 2009, Ürgüp, Nevşehir, Turkey. 
Gündüz, O., Okumuşoğlu, D., \& Baba, A. (2007). Acidic mining lakes and their influence on water quality: A case study from Can (Canakkale), Turkey, GQ07: Securing groundwater quality in urban and industrial environments. In Proc. 6th international groundwater quality conference held in Fremantle, Western Australia, 2-7 December 2007 (pp. 9-17).

Gündüz, O., Simsek, C., \& Hasozbek, A. (2009). Arsenic pollution in the groundwater of Simav Plain, Turkey: Its impact on water quality and human health. Water, Air and Soil Pollution, 205, 43-62.

Gündüz, O., Baba, A., \& Elpit, H. (2010). Arsenic in groundwater in Western Anatolia, Turkey: A review. In XXVIII IAH congress, groundwater quality sustainability (pp. 183-191). Krakow, Poland, 12-17 September.

Gürçay, S. (2004). Çanakkale kenti ve civarında özdirenç yöntemleriyle yeraltısuyu aramaları (p. 90). M.S. thesis, Çanakkale Onsekiz Mart University.

Haktanır, K. (1992). Pollutants transferred to soil through food chains. Turkish Journal of Agriculture and Engineering, 43, 42-43.

Hansen, L. D., \& Fisher, G. L. (1980). Elemental distribution in coal fly ash particles. Environmental Science \& Technology, 9(9), 862-868.

Helvacı, C. (2005). Borates. In: R. C. Selley, L. R. M. Cocks, \& I. R. Plimer (Eds.), Encyclopedia of geology (Vol. 3, pp. 510-522). Amsterdam: Elsevier.

Hem, J. D. (1985). Study and interpretation of the chemical characteristics of natural water (p. 2254). U.S. Geological Survey Water-Supply Paper.

Hulett, L. D., Weinberger, A. J., Northcutt, K. J., \& Ferguson, M. (1980). Chemical species in fly ash from coal burning power plants. Science, 210, 13561358.

Jackson, J. A., \& Mc Kenzie, D. P. (1984). Active tectonics of the Alpine-Himalayan belt between Western Turkey and Pakistan. Geophysical Journal of the Royal Astronomical Society, 77, 185-264.

Jones, F., \& Watkins, J. (1985). The water cycle as a source of pathogens. Journal of Applied Bacteriology, 14, 27-36.

Kaçaroğlu, F. (1999). Review of groundwater pollution and protection in karst areas. Water, Air, and Soil Pollution, 113(1-4), 337-356.

Kaçaroğlu, F., \& Günay, G. (1997). Groundwater nitrate pollution in an alluvium aquifer, Eskisehir urban area and its vicinity, Turkey. Environmental Geology, 31(3-4), 178-184.

Kaçaroğlu, F., Değirmenci, M., \& Cerit, O. (2001). Water quality problems of a gypsiferous watershed: Upper Kizilirmak Basin, Sivas, Turkey. Water, Air and Soil Pollution, 128(1/2), 161-180.

Kalavrouziotis, I. K., \& Alaton, I. A. (2008). The reuse of municipal wastewater effluents and sewage sludge in the irrigation of forested areas. Fresenius Environmental Bulletin, 17(6), 625-639.

Karadavut, U., Sener, O., \& Gozubenli, H. (1997). Analysis of water pollution due to agriculture activities. In Water and environment symposium proceedings (pp. 511-518). Istanbul, 2-5 June.
Karagüzel, R., \& Irlayici, A. (1998). Groundwater pollution in the Isparta Plain, Turkey. Environmental Geology, 34(4), 303-308.

Karagüzel, R., Scholz, R., \& Ebel, B. (1999). Hydrogeological investigation of Antalya basin concerning the future domestic water needs of Antalya City (Turkey). Environmental Geology, 38(2), 159-167.

Karamenderesi, I. H., \& Helvaci, C. (2001). Effects of geothermal sources around Buyuk Menderes River on groundwaters. In Groundwaters and environment symposium (pp. 339-350). Izmir, 21-23 March.

Kavcar, P., Sofuoglu, A., \& Sofuoglu, S. C. (2009). A health risk assessment for exposure to trace metals via drinking water ingestion pathway. International Journal of Hygiene and Environmental Health, 212(2), 216-227.

Klein, D. H., Andren, A. W., Carter, J. A., Emery, J. F., Feldman, C., Fulkerson, W., et al. (1975). Pathways of thirty seven trace elements through coal-fired power plant. Environmental Science \& Technology, 9(10), 973-978.

Kurt, M. A., Güler, C., Alpaslan, M., \& Akbulut, C. (2009). Comparison of the nitrate and nitrite levels in soils and groundwater of the area between Mersin and Tarsus. In 62nd Geological Kurultai of Turkey (p. 525). Ankara, Turkey, 13-17 April.

Misırlı, F., Basagaoglu, H., \& Yazıcıgıl, H. (1995). A comparison of two groundwater management models for optimal waste containment, assessing and managing health risks from drinking water contamination: Approaches and applications. In Proceedings of the Rome symposium (p. 277). IAHS Publ. no. 233.

Nicholson, K. (1993). Geothermal fluids-Chemistry and exploration techniques (p. 263). New York: Springer.

Oruc, N. (1977). Fluoride content of some spring water and fluorosis in the Eastern Anatolia. In Seminar on problems of high fluoride waters. Erzurum, Turkey, 67 September, Cento Scientific Program, report no: 28.

Oruc, N., \& Vicil, M. (2001). Source and limits of flourine in drinking water of Güllü village in Uşak-Eşme. In Groundwaters and environment symposium (pp. 213219). Izmir, 21-23 March.

Özçelik, S., \& Sarız, K. (2001). Positive developments after 1995 for groundwater pollution around Eskisehir Plain. In Groundwaters and environment symposium (pp. 231-245). Izmir, 21-23 March.

Özler, M. H. (2003). Hydrochemistry and salt-water intrusion in the Van Aquifer, East Turkey. Environmental Geology, 43(7), 759-775.

Özler, M. H., \& Aydın, A. (2008). Hydrochemical and microbiological quality of groundwater in West Thrace Region of Turkey. Environmental Geology, 54, 355363.

Öztaş, T. (1997). Effects of rapid urbanization on surface and groundwater in the example of IstanbulBakırkoy water catchments area and the importance of artificial recharge in the solution for existing problems of Bakirkoy aquifer. In Water and environment symposium (pp. 19-36).

Pehlivan, R., \& Yilmaz, O. (2005). Water quality and hydrogeochemical characteristics of the River 
Buyukmelen, Duzce, Turkey. Hydrological Processes, 19(20), 3947-3971.

Şardaş, S. (2009). Risk assessment in arsenic exposure, 1. In Medical Geology workshop (pp. 138-144). Nevşehir, Turkey, 30 October-1 November.

Selçuk, H., Güler, H., \& Kaçmaz, S. E. (2004). Evaluation of water quality and supplies by using geographical information systems in Istanbul. Fresenius Environmental Bulletin, 13(9), 906-909.

Şen, E. (1996). Bursa Nilüfer ve Ayvalı Havzalarındaki kaynak suyunda UV tekniği ile nitrat konsantrasyonu. In Uludag University, I. Uluda ̆̆ Çevre Mühendisliği Sempozyumu Kitabı (pp. 341-354). Bursa. Uludağ Üniversitesi Basımevi.

Sendil, C., \& Baysu, N. (1973). Fluoride pollution observed in humans and animals around Dogubeyazit-Agri City (Turkey), Ankara University. Veterinary Faculty Bulletin, 10, 474-489.

Şimsek, S. (1997). Geothermal potential in northwestern Turkey. Active tectonics of Northwestern Anatolia. In: C. Schindler \& M. Pfister (Eds.), The Marmara Poly-Project (pp. 111-123). Zurich: vdf hochschulverlag AG ander ETH.

Şimşek, C., Gemici, Ü., \& Filiz, Ş. (2008). An assessment of surficial aquifer vulnerability and groundwater pollution from a hazardous landfill site, Torbal1/Turkey. Geosciences Journal, 12, 69-82.

Şimşek, C., Yavuz, B., Elçi, H., Elçi, A., \& Gündüz, O. (2009). Impact of the disposal of sewage in ancient marble quarries on groundwater quality. In $62 \mathrm{nd} \mathrm{Ge-}$ ological Kurultai of Turkey (p. 155). Ankara, Turkey, 13-17 April.

Tayfur, G., Kirer, T., \& Baba, A. (2008). Groundwater quality and hydrogeochemical properties of Torbalı Region, Izmir, Turkey. Environmental Monitoring and Assessment, 146, 157-169.

Tayfur, G., Tanji, K. K., \& Baba, A. (2010a). Twodimensional finite elements model for boron management in agroforestry sites. Environmental Monitoring and Assessment, 160(1-4), 501-512.

Tayfur, G., Tanji, K. K., \& Baba, A. (2010b). Twodimensional finite elements model for selenium transport in saturated and unsaturated zones. Environmental Monitoring and Assessment, 169(1-4), 509-518.

Tayfur, G., Tanji, K. K., House, B., Robinson, F., Teuber, L., \& Kruse, G. (1995). Modeling deficit irrigation in alfalfa production. Journal of Irrigation and Drainage Engineering, 121(6), 442-451.

Uğurlu, A. (2004). Leaching characteristics of fly ash. Environmental Geology, 46(6-7), 890-895.

Ünak, P., Lambrecht, F. Y., Biber, F. Z., \& Darcan, S. (2007). Iodine measurements by isotope dilution analysis in drinking water in Western Turkey. Journal of Radioanalytical and Nuclear Chemistry, 273(3), 649-651.

Uslu, B. (1982). Endemic fluorosis, Aegean University. Medical School Bulletin, 21, 1019-1028.

WHO (2006). Fluoride in drinking-water. Geneva: World Health Organization.

Yazıcıgil, H., \& Ekmekci, M. (2003). Perspectives on Turkish ground water resources. Ground Water, 41(3), 290-291.

Yazıcıgil, H., Er, C., Sakiyan, A. J., \& Çamur, M. Z. (2009). Effects of solution mining on groundwater quality in the Kazan Trona Field, Ankara-Turkey: Model predictions. Environmental Geology, 57(1), 157-172.

Yiğitbas, E., Elmas, A., Sefunç, A., \& Özer, N. (2004). Major neotectonic features of eastern Marmara region, Turkey: Development of the Adapazar1-Karasu corridor and its tectonic significance. Geological Journal, 39, 179-198.

Yilmaz, S., Baba, B., Baba, A., Yagmur, S., \& Citak, M. (2009). Direct quantitative determination of total arsenic in natural hot waters by anodic stripping voltammetry at the rotating lateral gold electrode. Current Analytical Chemistry, 5(1), 29-34.

Yüce, G. (2006). The vulnerability of groundwater dependent ecosystems: A study on The Porsuk River Basin (Turkey) as a typical example. In A. Baba, et al. (Eds.), Groundwater and ecosystems (pp. 295-310). New York: Springer.

Yüce, G. (2007). Spatial distribution of groundwater pollution in the Porsuk River Basin (PRB), Turkey. International Journal of Environment and Pollution, 30(3-4), 529-547.

Yüce, G., Yasin, D. U., Ak, E., \& Say, T. (2009). Determination of radon concentration in water resources around Beylikova-Kaymaz-Pyhrigian Valley (Eskisehir-Turkey) and its risk assessment for human health. In 62nd Geological Kurultai of Turkey (p. 531). Ankara, Turkey, 13-17 April. 